\title{
ORTHODOX CATECHISM AFFECTS GENDER DIFFERENCES IN ADOLESCENTS' NEEDS FOR AFFILIATION AND ACHIEVEMENT AND ALTERS THEIR SENSE OF PURPOSE IN LIFE
}

Ana Volarevic ${ }^{1}$, Bojana Simovic Markovic ${ }^{2}$, Nikola Jankovic ${ }^{1}$, Sanja Bojic ${ }^{1}$, Nebojsa Zdravkovic ${ }^{1}$

${ }^{1}$ Faculty of Medical Sciences, University of Kragujevac, Serbia

${ }^{2}$ Centre for Molecular Medicine and Stem Cell Research, Faculty of Medical Sciences , University of Kragujevac, Serbia

\author{
UTICAJ PRAVOSLAVNOG IKATIHIZISA NA RAZLICITO ISPOLJAVANJE \\ SMISLA ŽIVOTA, AFILIJATIVNE MOTIVACIJE I MOTIVA POSTIGNUĆA \\ ADOLESCENATA MUŠKOG I ŽENSKOG POLA \\ Ana Volarevići ${ }^{1}$ Bojana Simović Marković 2 , Nikola Janković ${ }^{1}$, Sanja Bojić ${ }^{1}$, Nebojša Zdravković ${ }^{1}$ \\ ${ }^{1}$ Fakultet medicinskih nauka, Univerzitet u Kragujevcu, Kragujevac, Srbija \\ ${ }^{2}$ Centar za molekularnu medicinu i istrazivanje maticnih celija, Fakultet medicinskih nauka, Univerzitet u Kragujevcu, Kragujevac, Srbija
}

Received / Primljen: 22.02.2014.

Accepted / Prihvaćen: 25.02.2014.

\section{ABSTRACT}

Studies conducted among Catholics and Protestants have shown higher levels of prayer and religious experience among women compared to men and have suggested that these gender differences may be a reflection of differences in personality and socialization. However, the impact of orthodox religion on adolescents' psychological and social wellbeing remains unknown.

The aim of this study was to investigate the influence of Orthodox religious studies (Orthodox Catechism) on gender differences in adolescents' needs for affiliation and achievement and their effect on adolescents' attitudes about their purpose in life.

This study is the first to show that Orthodox Catechism affects adolescents' needs for affiliative and achievement motivation in a gender-dependent manner. Orthodox Catechism enhances the competition motives of male adolescents and has a significant influence on the development of emotional support and goal achievement as well as providing a source of pleasure for female adolescents. Thus, the Orthodox Catechism is related to gender differences in adolescents' sense of purpose in life.

In conclusion, our findings emphasize the effects of the Orthodox Catechism on the expression of adolescents' psycho-emotional characteristics, demonstrating that the Orthodox religion has a positive influence on adolescents' needs for affiliation and achievement and affects their attitudes about their purpose in life.

Keywords: Orthodox Catechism, gender, affiliation, achievement, motive, purpose in life

\section{SAŽETAK}

Studije sprovedene medu katolicima i protestantima su pokazali veći stepen religioznog iskustva kod žena u odnosu na muškarce, sugerišući da se ove razlike mogu odraziti i razlikama u psihološkim karakteristikama ličnosti i u njihovoj socijalizaciji i ponašanju. Međutim, uticaj pravoslavne religije na razvoj psiholoških $i$ socijalnih karakteristika adolescenata je $i$ dalje nepoznat.

Cilj ove studije je bio da se ispita uticaj učenja pravoslavne religije (Pravoslavni katihizis) na razlike medu polovima u razvoju i ispoljavanju motiva postignuća $i$ afilijativne motivacije adolescenata kao i da se utvrdi da li ove razlike utiču na stavove adolescenata o smislu života.

$U$ ovom radu, po prvi put je pokazano da Pravoslavni katihizis utiče na razvoj motiva postignuća $i$ afilijativne motivacije adolescenata različito kod muškaraca $i$ žena. Pravoslavni katihizis pojačava takmičarski motiv muških adolescenata, ima značajan uticaj na razvoj emocionalne podrške $i$ postizanje cilja kao izvor zadovoljstva ženskih adolescenata $i$ utiče na stavove adolescenata o smislu života.

Rezultati predstavljeni u ovom istraživanju ukazuju da Pravoslavni katihizis utiče na ekspresiju psiho-emocionalnih karakteristika adolescenata pokazujući da pravoslavna religija ima pozitivan uticaj na razvoj motiva postignuća, afilijativne motivacije $i$ da na pozitivan način utiče na stavove adolescenata o smislu života.

Ključne reči: Pravoslavni katihizis, pol, afili-jativna motivacija, motiv postignuća, smisao života 


\section{INTRODUCTION}

For believers, complete and true devotion and obedience to God is a constant source of spiritual, emotional, and moral energy and is helpful in resisting destructive environmental attacks as well as social and mental disruption (1). For the past few decades, researchers have systematically investigated connections between religiosity and mental health and have identified a consistent relationship between them in adolescent populations (2-5).

Higher levels of religiosity and spirituality in adolescents have been associated with better mental health (6), a reduction in the negative effects of psychiatric disorders on suicidal thoughts (7-8), and protective effects for the emotional and physical well-being of adolescents exposed to traumatic events (9-10).

A general conclusion in the psychological literature is that women are more religious than men (11). Studies conducted among Catholics and Protestants have shown higher observance of prayer and religious experience among women compared to men, suggesting that these gender differences may reflect differences in personality and socialization (11).

Affiliation and achievement motives are important for the psychological and social well-being of young adults (12). Achievement motivation is an important issue for psychologists of religion because it has been correlated with personality traits and religiosity (12). Moreover, gender differences in achievement motivation have been studied widely in the context of academic achievement (13) because gender differences in motivation have been found to predict adolescents' differences in academic achievement (14).

Affiliative motivation, defined as the desire to get along with another person to create, preserve, or re-establish positive relations, is closely related to religiosity. Religion helps people to affiliate and coordinate with one another to maintain a distinctive social identity (15-16). However, this positive effect of religion on affiliative motivation may be culture-specific. Many religious traditions differentiate between the religious obligations of men and women, which also affects affiliative motivation (17).

The influence of religiousness on adolescents' needs for affiliation and achievement is carried over direct physiological pathways. Religious studies have examined gender differences in these personal traits, and a positive association has been found between intrinsic religious orientation and a sense of purpose in life among Catholics and Protestants (18-19). A greater sense of purpose in life has also been found among intrinsically religiously oriented adolescents of both genders. A sense of purpose in life is positively related to the happiness, life satisfaction, and general psychological well-being of young adults (19). In addition, religious education has a positive impact on the sense of purpose in life, and individuals who describe themselves as having strong religious faith are happier and more satisfied with their lives. This finding indicates that spirituality and religiosity are important psychologi- cal mechanisms for managing adolescents' stressful life events (6).

The consistency of the previously discussed findings across a diversity of samples, designs, methodologies, religiousness, and population characteristics serves to strengthen the inference of a positive association between religion and adolescents' emotional well-being. However, all of these studies were conducted among Catholics, Protestants, Jews, and Muslims. The impact of Orthodox religion on adolescents' needs for affiliation and achievement remains unknown.

This research examines the influence of the Orthodox religion (Orthodox Catechism) on the gender differences in adolescents' needs for affiliation and achievement that affect their attitudes about their purpose in life.

\section{MATERIALS AND METHODS}

\section{Participants}

The participants in this study were adolescents (18-21 years old) who were students of the Faculty of Medical Sciences, University of Kragujevac, Serbia $(\mathrm{N}=435)$. Male and female participants were divided into two groups depending on their studies during high school: Orthodox Catechism or civic education. The study was approved by the Ethical Committee of the Faculty of Medical Sciences, University of Kragujevac, Serbia.

\section{Psychological tests}

The students responded to standardized psychological tests (the purpose in life scale, the need for affiliation test, and the need for achievement test) that were previously standardized in the Serbian population .

\section{Need for achievement test}

The need for achievement test was used to measure the achievement motivation of adolescents. This test is an adaptation of the original scale constructed by David McClellan (20). It contains 55 items that assess four factors of achievement motivation: competition (example: "The biggest motivation for me is competition with others"), perseverance in achieving a goal (example: "I always finish the job that I started"), achievement of a goal as a source of pleasure (example: "Just the thought that I managed to accomplish a goal is positive for me"), and orientation towards planning (example: "I feel great satisfaction when I manage to complete my daily plan"). These four components are independent of each other, and together they form a general achievement motivation factor that is highly correlated with all four sub-factors. The participants responded on a 5-point scale ranging from 1 ("not true of myself") to 5 ("definitely true of myself"). The scale of the negatively worded items (numbers 14, 16, 18, 19, 47, 49, 52, 
and 55) was reversed before the sum of all items was taken. The total score was calculated as the sum of all items.

Adolescents who scored higher on the "competition" sub-scale have a competitive spirit, a desire to be better than others, and a need to show people how successful they are. Adolescents who scored higher on the "perseverance in achieving the goal" sub-scale are willing to spend manysignificant time and effort to achieve a goal; they know what they want, and they do not give up despite the odds. Respondents who scored high on the "achievement of the goal as a source of pleasure" sub-scale feel good when they achieve their goals. Adolescents with high scores on the "orientation towards planning" sub-scale prefer to plan their activities in advance.

\section{Need for affiliation test}

The need for affiliation test is an adaptation of the Interpersonal Orientation Scale by Craig Hill (21). This scale has been used to operationalize affiliation. The original scale consists of 26 items grouped in four subscales determining four factors of affiliative motivation: emotional support (example: "Whenever something bad happens to me, it is most helpful for me to spend time with my intimate friends"), social comparison (example: "When I am not sure how good I am, it helps me to compare myself with other people"), positive stimulation (example: "The fact that I can learn something about people gives me great pleasure"), and attention (example: "I enjoy when people think that I am an important person"). Participants responded on a 5 -point scale ranging from 1 ("not true of myself") to 5 ("definitely true of myself"). The total score was calculated as the sum of all items. Adolescents who had higher scores are considered to be "highly affiliated"; they more often seek social contact with others, communicate more often with colleagues, and visit friends more frequently than others. If a respondent had a high score in only a single dimension of affiliative motivation, this type of affiliative motivation is his/her main motivation for entering into social contacts.

\section{The purpose in life scale}

The purpose of life scale is used to assess adolescents' sense of purpose and meaning in life. This scale is an adaptation of the purpose in life test by James Crumbaugh (22). It consists of 23 items that assess the emotional and cognitive aspects of purpose in life (representative items: "I have discovered satisfying goals and a clear purpose in life"; "If I should die today, I would feel that my life has been worthwhile"; "My personal existence often seems meaningless and without purpose"). The participants responded on a 5-point scale ranging from 1 ("not true of myself") to 5 ("definitely true of myself"). The scale of the negatively worded items (numbers $1,3,5,6,7,8,12,15,16$, and 20) was reversed before the sum of all items was taken. The total score was calculated as the sum of all items.

\section{Procedure}

The psychological tests, standardized for the Serbian population, were administered anonymously to the students in their classrooms. The students volunteered for the study after the tester briefly explained its purpose and assured them that anonymity would be maintained. If any student did not want to participant, he/she was allowed to leave the testing session. The data were collected and analyzed by a trained psychologist.

\section{Statistical analysis}

All statistical analyses were conducted using SPSS 19.0 for Windows software. The results were analyzed using Student's t-test or a Mann-Whitney test on the dependence of normal distribution determined by a Kolmogorov-Smirnov test. Correlation between the values was determined by Pearson's correlation. The data were expressed as the mean \pm standard error (SEM). Values of $\mathrm{p}$ $<0.05$ were considered statistically significant.

\section{RESULTS}

\section{Orthodox Catechism enhances achievement of the goal as a source of pleasure among female adolescents}

As shown in Figure 1, Orthodox religious education enhances the motivation to achieve goals as a source of pleasure among female adolescents. Female students had significantly higher scores on the "achievement of the goal as a source of pleasure" sub-scale in comparison with male students $(p<0.01)$. The results from the male and female adolescents who studied civic education, who were used as the control group in this test, showed no significant difference on the "achievement of the goal as a source of pleasure" sub-scale among these participants.

The Pearson correlation test further confirmed the influence of the Orthodox Catechism on the development of motivation for the achievement of a goal as a source of pleasure among female adolescents. There was a significant correlation between gender and the score on the "achievement of the goal as a source of pleasure" sub-scale among students who studied the Orthodox Catechism $(r=0,223 ; \mathrm{p}<0,01)$, whereas there was no significant correlation in these parameters among adolescents who studied civic education.

\section{Orthodox Catechism enhances competition motive of male adolescents}

The results obtained for the "competition" sub-scale of the need for achievement test (Figure 2) showed a significantly higher score among male adolescents who studied Orthodox Catechism compared to female students ( $\mathrm{p}<$ 


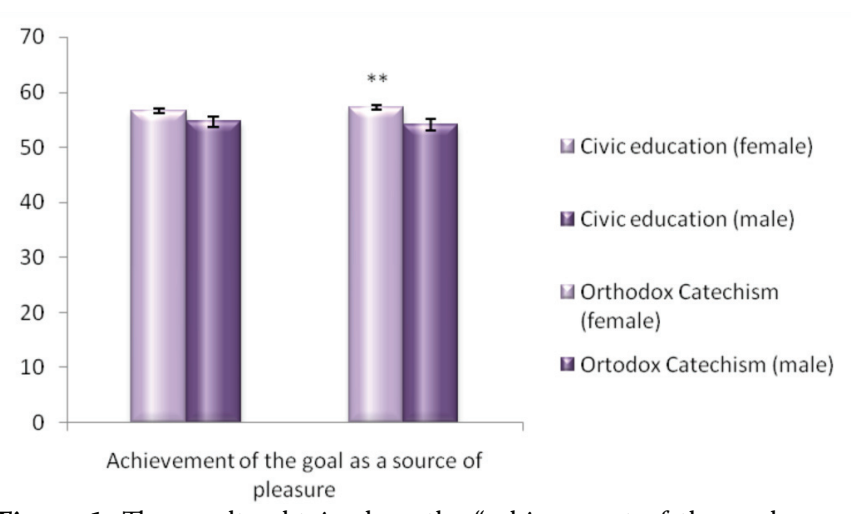

Figure 1. The results obtained on the "achievement of the goal as a source of pleasure" sub-scale of the need for achievement test

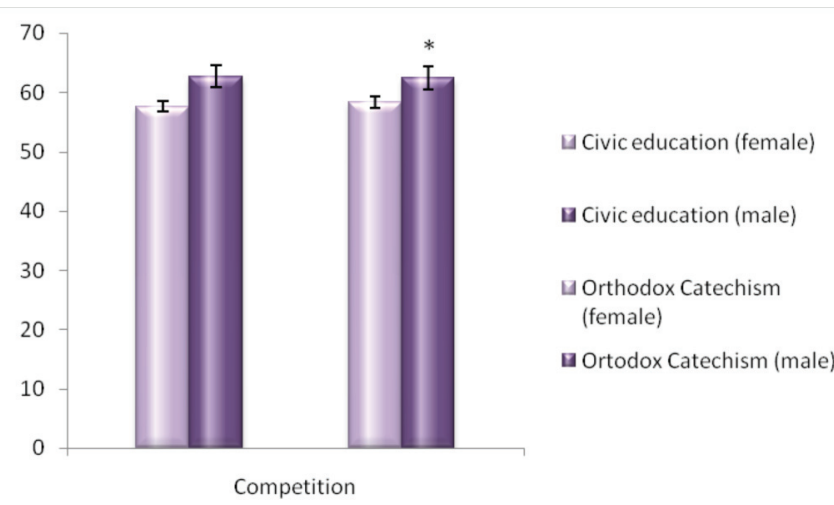

Figure 2. The results obtained on the "competition" sub-scale of the need for achievement test

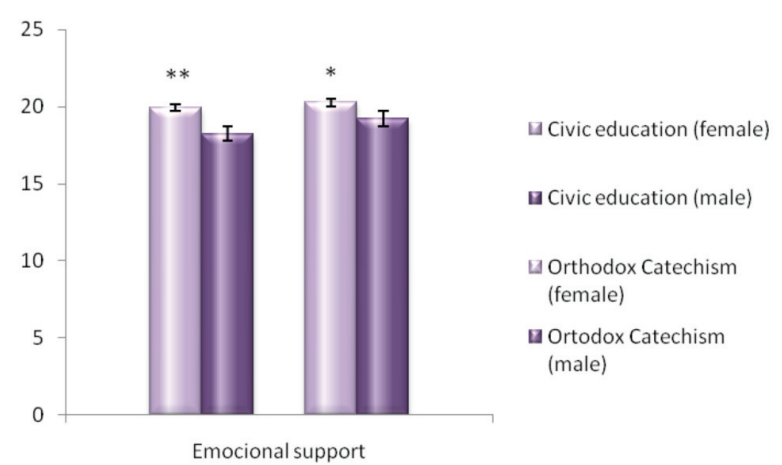

Figure 3. The results obtained on the "emotional support" sub-scale of the need for affiliation test

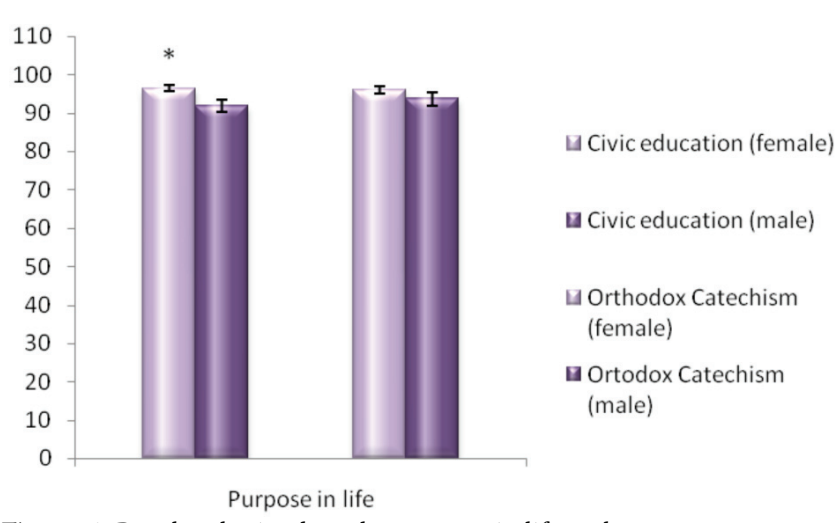

Figure 4. Results obtained on the purpose in life scale
0.05). On the contrary, there was no significant difference in the "competition" sub-scale between male and female adolescents who studied civic education, suggesting that the Orthodox Catechism enhances the competition motives of male adolescents.

As shown in Table 1, there were no significant differences for the scores on the "perseverance in achieving the goal" and "orientation toward planning" sub-scales between the examined participants, suggesting that competition motives and achievement of the goal as a source of pleasure were mainly affected by the Orthodox Catechism.

Orthodox Catechism has a significant influence on the development of emotional support as a major affiliative motive among female adolescents

The results obtained on the need for affiliation test (Figure 3) showed that emotional support is the main affiliative motive of female adolescents who studied Orthodox Catechism $(\mathrm{p}<0.05)$ and civic education $(\mathrm{p}<0.01)$.

The Pearson correlation test showed a significant correlation between gender and emotional support only among adolescents who studied the Orthodox Catechism $(\mathrm{r}=0,145 ; \mathrm{p}<0,05)$, indicating that the Orthodox Catechism has a significant influence on the development of emotional support as a major affiliative motive among female adolescents.

As shown in Table 1, there were no significant differences for the scores on the sub-scales determining social comparison, positive stimulation, and attention between the examined participants, suggesting that emotional support is the main motive for female adolescents to enter into social contacts.

\section{Orthodox Catechism affects male adolescents' sense of purpose in life}

Only among adolescents who studied civic education, there was significant but negative correlation between gender and the purpose in life score $(\mathrm{r}=-0,159 ; \mathrm{p}<0,05)$. Additionally, female adolescents who studied civic education scored significantly higher on the purpose of life scale compared to male students who studied civic education. As shown in Figure 4, Orthodox Catechism affects male adolescents' sense of purpose in life. Male adolescents who studied the Orthodox Catechism scored higher on the purpose of life scale then male students who studied civic education, with a loss of statistical significance between the genders among adolescents who studied the Orthodox Catechism.

\section{DISCUSSION}

The role of Orthodox religion in the expression of the psycho-emotional and social characteristics of adolescents is completely unknown. This study is the first to demon- 


\begin{tabular}{|l|l|l|}
\hline Sub-scale & $\begin{array}{l}\text { Orthodox Catechism } \\
\text { female vs. male } \\
\text { (Mean } \pm \text { SE) }\end{array}$ & $\begin{array}{l}\text { civic education } \\
\text { female vs. male } \\
\text { (Mean } \pm \text { SE) }\end{array}$ \\
\hline Perseverance in achieving the goal & $61.37 \pm 0.56$ vs. $60.02 \pm 1.14$ & $60.56 \pm 0.57$ vs. $58.54 \pm 0.93$ \\
\hline Orientation toward planning & $26.66 \pm 0.59$ vs. $26.65 \pm 0.99$ & $27.29 \pm 0.49$ vs. $25.71 \pm 1.02$ \\
\hline Social comparison & $12.69 \pm 0.22$ vs. $12.58 \pm 0.47$ & $12.52 \pm 0.20$ vs. $13.29 \pm 0.34$ \\
\hline Positive stimulation & $16.76 \pm 0.31$ vs. $17.00 \pm 0.50$ & $16.49 \pm 0.26$ vs. $16.10 \pm 0.46$ \\
\hline Attention & $12.17 \pm 0.31$ vs. $13.17 \pm 0.46$ & $12.03 \pm 0.22$ vs. $12.40 \pm 0.43$ \\
\hline
\end{tabular}

Table 1. The mean values obtained on the need for achievement and need for affiliation tests

strate that Orthodox religious education shows gender differences in adolescents' needs for affiliation and achievement, altering their sense of purpose in life.

Numerous studies have examined the relationship between religiosity and gender differences with regard to affiliative and achievement motivation (15-16, 23-24). This study is the first to show that the Orthodox Catechism significantly enhances the achievement of a goal as a source of pleasure among female adolescents (Figure 1) and enhances the competition motive of male adolescents (Figure 2). Our data are in line with the results obtained by Allan Wigfield (25), suggesting that male students are more likely to express a competition motive due to their higher competence beliefs in sports activities, whereas female adolescents are more likely to express achievement motives that are related to social activities, satisfaction, and enjoyment. It seems that Orthodox religious education stimulates the expression and/or development of achievement motives, which are rooted in the socialization processes of male and female adolescents (23). These findings are consistent with the notion that religious education serves the relational function of establishing a shared sense of reality that helps to maintain and coordinate important social relationships (12). We are the first to show the relation between the Orthodox religion and emotional support. Our data indicate that the Orthodox Catechism has a significant influence on the development of emotional support as a major affiliative motive among female adolescents (Figure 3). Our data are in line with previous studies conducted among Protestants and Catholics, as reviewed by Ji and colleagues (26), supporting the belief that the Christian religion advances the development of emotional support among female adolescents. Importantly, these pro-social traits or emotional dispositions are typical of religiosity not only among Protestants and Catholics but also among Buddhists, Jews, and Muslims (26). According to Saroglou (27), religious people tend to attribute high importance to the value of benevolence, which is the motivational essence of emotional support. Religious people feel, think, and value things in a way that emphasizes the importance of others' interests and needs, suggesting pro-sociality as a key and universal characteristic of religious personality (27). It should be emphasized that among Protestants, Catholics, and Hindus, women are concluded to be more religiously active than men and have strongly expressed motives toward emotional support (11). In line with these findings, our data indicate that among Orthodox Christians, emotional support is the main affiliative motive and is particularly expressed among women.

A strong and an intrinsic religious orientation might be sufficient for young adults to achieve a sense of purpose in life. In turn, purpose in life is positively associated with life satisfaction and has a strong positive correlation with subjective well-being (19). Accordingly, we found that male adolescents who studied Orthodox Catechism had a higher score on the purpose of life scale then male students who studied civic education, with a loss of statistical significance between genders among adolescents who studied Orthodox Catechism. Our results are in line with data obtained by Martin Pinquart, who found small gender differences and an age-associated decline of purpose in life only in populations of older adults (28). According to Pinquart, there are no gender differences in purpose in life among young adults because most middle-aged people experience, for the first time, age-associated losses of sources of their purpose in life after they realize that some of their previous long-term goals are not realistic (28).

\section{CONCLUSIONS}

This study is the first to show that the Orthodox Catechism affects adolescents' needs for affiliative and achievement motivation in a gender-dependent manner. The Orthodox Catechism enhances the competition motives of male adolescents and has a significant influence on the development of emotional support and achievement of goals as a source of pleasure among female adolescents. Thus, the Orthodox Catechism is related to gender differences in adolescents' sense of purpose in life.

\section{CONFLICT OF INTEREST}

The authors who participated in this study declare that they do not have anything to disclose regarding funding or conflicts of interest with respect to this manuscript.

\section{ACKNOWLEDGEMENTS}

We thank Professor Nebojsa Arsenijevic for his comments and support. 


\section{REFERENCES}

1. Pajević I, Sinanović O, Hasanovic M. Religiosity and mental health. Psychiatria Danubina 2005; 17: 84-89.

2. Cotton S, McGrady ME, Rosenthal SL. Measurement of religiosity/spirituality in adolescent health outcomes research: trends and recommendations. Journal of Religion and Health 2010; 49: 414-444.

3. Baroun KA. Relations among religiosity, health, happiness, and anxiety for Kuwaiti adolescents. Psychological Reports 2006; 99: 717-722.

4. Bonelli RM, Koenig HG. Mental disorders, religion and spirituality 1990 to 2010: a systematic evidence-based review. Journal of Religion and Health 2013; 52: 657-673.

5. Yonker JE, Schnabelrauch CA, Dehaan LG. The relationship between spirituality and religiosity on psychological outcomes in adolescents and emerging adults: a meta-analytic review. Journal of Adolescence 2012; 35: 299-314.

6. Wong Y, Rew L, Slaikeu K. A systematic review of recent research on adolescent religiosity/spirituality and mental health. Issues in Mental Health Nursing 2006; 27: 161-183.

7. Nkansah-Amankra S, Diedhiou A, Agbanu SK, Agbanu HL, Opoku-Adomako N, Twumasi-Ankrah P. A longitudinal evaluation of religiosity and psychosocial determinants of suicidal behaviors among a populationbased sample in the United States. Journal of Affective Disorders 2012; 139: 40-51.

8. Hoffman S, Marsiglia F. The Impact of Religiosity on Suicidal Ideation Among Youth in Central Mexico. Journal of Religion and Health 2014; 53: 255-266.

9. Korn L, Zukerman G. Affective and behavioral changes following exposure to traumatic events: the moderating effect of religiosity on avoidance behavior among students studying under a high level of terror event exposure. Journal of Religion and Health 2011; 50: 911-921.

10. Laufer A, Solomon Z. The role of religious orientations in youth's posttraumatic symptoms after exposure to terror. Journal of Religion and Health 2011; 50: 687-699.

11. Loewenthal K, MacLeod A, Cinnirella M. Are women more religious than men? Gender differences in religious activity among different religious groups in the UK. Personality and Individual Differences 2001; 32: 133-139.

12. Shekhar C, Devi R. Achievement Motivation across Gender and Different Academic Majors. Journal of Educational and Developmental Psychology 2012; 2: 105-109.

13. Meece J, Glienke B, Burg S. Gender and motivation. Journal of School Psychology 2006, 44: 351-373.
14. Steinmayr R, Spinath B. Sex differences in school achievement: what are the roles of personality and achievement motivation? European Journal of Personality 2008; 22: 185-209.

15. Graham J, Haidt J. Beyond beliefs: Religions bind individuals into moral communities. Personality and Social Psychology Review 2010; 14: 140-150.

16. Hogg M, Adelman JR, Blagg RD. Religion in the face of uncertainty: An uncertainty-identity theory account of religiousness. Personality and Social Psychology Review 2010; 14: 72-83.

17. Norenzayan A, Shariff AF. The origin and evolution of religious prosociality. Science 2008; 322: 58-62.

18. Rankin LE, Jost J, Wakslak C. System justification and the meaning of life: Are the existential benefits of ideology distributed unequally across racial groups? Social Justice Research 2009; 22: 312-333.

19. Ardelt M. Effects of Religion and Purpose in Life on Elders' Subjective Well-Being and Attitudes Toward Death. Journal of Religious Gerontology 2003; 14: 55-77.

20. McClellan D, Boyatzis R. Leadership Motive Pattern and Long-Term Success in Management. Journal of Applied Psychology 1982; 67: 737-743.

21. Hill C. Social support and health: The role of affiliative need as a moderator. Journal of Research in Personality 1987; 21: 127-147.

22. Crumbaugh J. Cross-validation of Purpose in Life Test based on Frankl's concepts. Joumal of Individual Psychologv 1968; 24: 74-81.

23. Pancer SM, Jackson LM, Hunsberger B, Pratt M, Lea J. Religious orthodoxy and the complexity of thought about religious and nonreligious issues. Journal of Personality 1995; 63: 213-232.

24. Shaffer LS. Religion as a large-scale justification system: Does the justification hypothesis explain animistic attribution? Theory \& Psychology 2008; 18: 779-799.

25. Wigfield A. Reading motivation: A domain-specific approach to motivation. Educational Psychologist 1997; 32: 59-68.

26. Ji C, Pendergraft L, Perry M. Religiosity, Altruism, and Altruistic Hypocrisy: Evidence from Protestant Adolescents. Review of Religious Research 2006; 48: 156-178.

27. Saroglou V. Religion and the five factors of personality: A meta-analytic review. Personality and Individual Differences 2002; 32: 15-25.

28. Pinquart M. Creating and maintaining purpose in life in old age: a meta- analysis. Ageing International 2002; 27: 90-114. 